\title{
Convenience of accounting education for the requirements of Saudi labour market: An empirical study
}

\author{
Nabil Ahmed Mareai Senan ${ }^{\mathbf{a}, \mathbf{b}^{*}}$
}

${ }^{a}$ Assistant Professor, Accounting Department, College of Business Administration, Prince Sattam Bin Abdulaziz University, Al-Kharj, Saudi Arabia

${ }^{b}$ Assistant Professor, Accounting Department, Administrative Science College, Al-Baydha University, Yemen

\section{H R O N I C L E}

Article history:

Received: April 82019

Received in revised format: April

282019

Accepted: May 28, 2019

Available online:

June 1, 2019

Keywords:

Accounting graduates

Accounting education

Saudi labor market

Accounting knowledge and skills

Employability

\section{A B S T R A C T}

Saudi labour market is unique in nature due to a number of aspects. It provides a picture of increasing job opportunity and, at the same time, higher level of youth unemployment. Like other countries, the employability of accounting graduates of Saudi Arabia is also subject to doubts. The present study assesses the convenience of accounting education for the unique requirements of Saudi labour market. The study collects data from 914 respondents from the three main stakeholders students, faculty and accounting practitioners. The study finds that all the three stakeholders were of the opinion that the education was capable of meeting the unique requirements of the labour market in Saudi Arabia. A few suggestions are also presented, which would help improve the outcomes of the accounting programs and make the graduates employable.

C 2019 by the authors; licensee Growing Science, Canada

\section{Introduction}

In the present highly competitive, volatile and uncertain business world, employers are on the lookout for employees who are industry ready and in procession of a wide range of abilities, skills and knowledge. They are expected to demonstrate that they are capable of responding to all the requirements of a highly diverse and dynamic workplace. This is all important with respect to accounting practitioners, who are expected to possess a wide range of skills and knowledge due to the worldwide adoption of International Financial Reporting Standards (IFRS). Now there is a general view among the employers that accounting programs of universities are incapable of providing their graduates with the required skills and capabilities (Hakim, 2016). There is a definite expectation-reality gap between the employers' need and the supply by the university system. This gap or mismatch makes the early experiences of fresh graduates at their work place to be far from satisfactory. The present study intends to assess the gap between the employers' requirements and the actual skills possessed by the university graduates who received their

\footnotetext{
* Corresponding author

E-mail address: n.senan@psau.edu.sa (N. A. M. Senan)

C 2019 by the authors; licensee Growing Science, Canada doi: $10.5267 /$ j.msl.2019.6.001
} 
degrees in accounting. This work also attempts to assess the preparedness of graduate in the accounting stream to take up the challenging tasks.

The need for the study stems from the fact that the atmosphere in which accounts are presently working is changing at a rapid pace. This pace is aided and accelerated by globalization and advancements in information technology (IT). These changes are posing unexpected challenges to the accounting profession. To face these challenges, there is a definite requirement to make the accounting programs provide students with strong and essential professional, technical and soft skills. The International Education Standard (IES) brought out by the International Accounting Education Standards Board (IAESB) (2015) identified four competencies that are required for professional accountants - intellectual, interpersonal and communication, personal, and organisational. Further, the decision of Saudi Organisation for Certified Public Accountants (SOCPA) to transition of Saudi Arabia towards International Financial Reporting Standards (IFRS) in 2012, has also presented the requirement to examine the quality of accounting education in the country. There is also a need to examine the steps taken by higher education institutions in Saudi Arabia to incorporate IFRS in their respective curriculums. The present study is undertaken in this backdrop.

\section{Review of literature}

The quality of higher education in general, and that of accounting education in particular has been a major issue of debate worldwide (Awayiga et al., 2010; Sulphey, 2017; Sulphey \& Al Kahtani, 2018; Zureigat, 2015). There are many who opine that the present educational model for accounting has failed in the area of employability skill development. This has resulted in problems for graduates as they lack the required generic skills (Muda et al., 2009), thereby dissuading them from pursuing successful careers (Abayadeera \& Watty, 2014; Muda, et al., 2009). One of the agencies associated with the development of the education systems in Saudi Arabia is NCAAA which conducts developmental review programs that have profound positive impact on the implementation of the requirements of standard four in the accounting program (Senan, 2018). Accounting employees are expected to have a set of generic as well as technical and functional skills (Barrie, 2006; Daff et al., 2012). According to Barrie (2006):

"Generic skills are the skills, knowledge, and abilities of university graduates, beyond the technical and discipline knowledge, which apply and transfer to different contexts and are required as the result of completing any undergraduate degree"

\section{Table 1}

Framework of Generic skills

\begin{tabular}{llll}
\hline \multicolumn{2}{c}{ Skills } & \multicolumn{1}{c}{ Particulars } \\
\hline & Cognitive & $\begin{array}{l}\text { Includes skills like routine, } \\
\text { analytic, appreciative, etc. }\end{array}$ & $\begin{array}{l}\text { Relate to abilities of students that evaluates, analyses, } \\
\text { interprets and capability of reporting data/ infor- } \\
\text { mation }\end{array}$ \\
Generic skills & Behavioural & $\begin{array}{l}\text { Intrapersonal - Managing self, being flexible in vari- } \\
\text { sonal skills }\end{array}$ & $\begin{array}{l}\text { Interpersonal - Communicating, dealing with people, } \\
\text { negotiating, etc. }\end{array}$ \\
\hline
\end{tabular}

Source Daff et al. (2012)

\subsection{Perception of employers about skills required by accounting graduates}

There have been substantial works accomplished on pertaining the skills sought by employers from accounting students (Daff, et al., 2012; Jackling \& De Lange, 2009). Evidences indicate that majority of employers place generic skills of accounting students in the high pedestal (Jackling \& De Lange, 2009) than others. This is because such skills are perceived to facilitate employees to put to better use of the technical skills acquired by them and be successful in their professions. Employers mostly assume that graduates acquire the required technical skills while they undergo their curriculum at colleges. The only 
difference is that based on the unique situations and context of each country, the relative importance of the skills as perceived by employers varies. It would now be imperative to examine the available studies about the skills that are considered as important in various countries across the globe. The details are presented in Table 2.

Table 2

Employers perception of Accountant's Generic skills across the globe

\begin{tabular}{lll}
\hline \multicolumn{1}{c}{ Country } & \multicolumn{1}{c}{ Skills } & \multicolumn{1}{c}{ Author } \\
\hline Australia & $\begin{array}{l}\text { Communication, teamwork, self-management, initiative, analyti- } \\
\text { cal/problem solving, business awareness and planning }\end{array}$ & $\begin{array}{l}\text { Kavanagh \& Drennan (2008); } \\
\text { Tempone et al. (2012) }\end{array}$ \\
Japan & $\begin{array}{l}\text { Information, judgmental, behavioural skills } \\
\text { South Africa }\end{array}$ & Communication, interpersonal, time management, analytical skills \\
Tunisia & Ethical awareness, communication, analysis and teamwork & Barac (2009) \\
Spain & Commitment to life-long learning, problem solving, global vision & Hassall et al. (2005) \\
UK & A host of communication skills like oral, written, listening, etc. & Hassall et al. (2005) \\
Saudi Arabia & Critical Thinking, Problem and Decision Analysis skills, Commu- & Zureigat (2015). \\
& nication skills (both written and oral), Ethics, Time Management, & \\
& IT, Leadership, etc. & \\
\hline
\end{tabular}

However, a study by Mallak (2012) found that employers of Saudi Arabia seem to differ from other countries with respect to the skills required by accountants. According to these studies, employers placed technical accounting skills at higher importance than generic skills.

The skills required by accountants have changed drastically due to the present fiercely dynamic business environment and the adaption of IFRS. Now they do more than keeping numbers and often serve as consultants to the top management (Dandago \& Shaari, 2013; Jones \& Abraham, 2009). They have to now work as information facilitators and strategic analysts, which demand a high level of interpersonal skills.

Employers always seek and are on the lookout for fresh graduates who are capable of applying their learned skills at work place. Many employers are of the opinion that accounting graduates are not taught and hence do not acquire the required generic skills at the universities. There are empirical evidences to prove that the education system has failed in many instances to meet the standards that are expected by employers of accounting graduates in certain crucial areas like critical thinking, communication (oral and written), inter-personal relations, ethical orientation, leadership development, Information technology (IT), and the like (Kavanagh \& Drennan, 2008; Daff et al., 2012; De Lange et al., 2009; Jackling \& Gut, 2006; Lin et al., 2005; Parham et al., 2012; Yu et al., 2013).

\subsection{Perception of students}

Perception of students regarding the skills required by accountants has also been subjected to empirical examination by many researchers (Usoff \& Feldmann, 1998; Klibi \& Oussii, 2013; Yu et al., 2013). These studies suggest that graduate students perceived technical skills to be of greater importance, as against generic skills. They tend to focus mostly on routine technical/accounting programs and research skills (Jackling \& De lange, 2009; Kavanagh \& Drennan, 2008). However, some studies also found continuous learning, communication skills (written and oral), problem solving and appreciative skills to be perceived as important by students (Kavanagh \& Drennan, 2008; Kim et al., 1993). A surprising finding by Kim et al. (1993) was that most accounting graduates firmly believed that good grades in the examinations and certain personal qualities were considered by employers as important. Students also perceive that they are not being provided with the required employability skills. According to Jackling and Sullivan (2007) students are of the opinion that they are to be provided with a "holistic learning experience that combines structured learning, with industry participation, work experience and extra- curricular activities". 
Thus, there exists a wide gap between the employers' and accounting graduates' perception regarding their preparedness and perceived employability skills (especially generic attributes), and this has been a matter of considerable discussions in the academic and industry circles (Abayadeera \& Watty, 2014; Brui \& Porter, 2010; Hakim, 2016; Siegel et al., 2010; Wally-Dima, 2011; Yu et al., 2013).

\subsection{Towards new curriculum and pedagogies}

The drastic changes in the business world have called for overhauling of the curriculum to make the students meet the modern challenges (Sulphey et al., 2018). In the accounting sphere many changes have been introduced in the recent past, including the adoption of IFRS, where accountants are expected to work as information facilitators and strategic analysts have thrust upon business educators the added responsibility of preparing graduates such that they are capable of satisfying the employer's requirements. However, researchers, for instance Athiyaman (2001) and Kavannah and Drennan (2008), are of the opinion that the available accounting curriculums of universities the world are mostly designed such that they are capable of providing only theoretical accounting base, rather than employability skills. Cranmer (2006) rues that generic skills are provided only scant attention by the universities, and whatever is taught does not add value to their employability skills. This view is also shared by Abayadeera and Watty (2014); Jackson and Chapman (2012) and Yu et al., (2013). In addition, there are doubts, vagueness and confusions regarding the exact requirements and expectations of the employers (Cranmer, 2006; Gati, 1998). Echoing this view Crawford et al. (2011) states that employers and students do not have clarity regarding the skills that is required. This difference could be due to the lack of appropriate communication channels between employers, the university and faculty, as the students. All these point towards the reason as to why accounting graduates face difficulties at their early careers. Accounting educators thus have a profound need and responsibility to have sound knowledge about the skills required skills by the students so that the curriculum and the courses could be appropriately improved, and the students can be prepared to take on the challenges that they could face in the work environment.

IFRS has thrust upon universities a golden opportunity for implementing new curriculum that uses latest pedagogies. However, there are many who rue (for instance AlMotairy \& Stainbank, 2014; Jackling et al., 2013) that academics have missed the opportunity to revise the contents and pedagogy of accounting curriculum. Jackling et al. (2013) suggest academics to adapt a "principle based approach" that could include "simulations, role plays, oral presentations by students and problem-based case studies with multiple solutions". In Saudi Arabia accounting education still has predominance towards traditional approaches, as lecturing is given more importance (AlMotairy \& Stainbank, 2014). There is a definite need to rethink about using latest pedagogical methodologies that adopt a student-centred approach. The utilization of modern pedagogies is now at a dismally low level. There should be a positive movement away from this towards a framework-based teaching. Using a framework-based teaching where the IFRS concepts form "the starting point and the basis for defining and analysing business transactions and economic events" will go a long way in modernising accounting education (Hodgdon et al., 2011; Wells, 2011). Towards this there should be more focus on the content, the way courses are delivered, as well as the curriculum structure.

This positive change in accounting education should focus on developing the skills of students in the areas of analysis and judgement (Barth, 2008; Carmona \& Trombetta, 2010). Towards this there is a need to follow a "conceptual approach to teaching". In such an approach the prime focus should be on principles, framework and concepts so that employability of graduates is enhanced. Such a framework approach will present the students with a better and lasting effect on employability as it will improve comprehension capacity. It will also help students adapt quickly to future changes in regulations and standards of accounting practices, which may not be provided by traditional and conventional teaching methodologies (Barth 2008). As against "conceptual based approach", there are others who firmly believe that IFRS can be taught better through a "framework-based teaching". For instance, Wells (2011) opine that accounting 
graduates have a necessity to develop and utilise a host of skills that include technical, professional and judgemental for IFRS reporting. He argues that towards this there is a need to develop a "frameworkbased teaching" of IFRS. This is because; there is a definite need to understand the various principles, concepts and framework of IFRS. The "framework-based teaching" allows having a deeper, comprehensive and better understanding of IFRS requirements and concepts. It will also help in developing abilities that will help in the exercising of professional judgment. There are empirical evidences to suggest that such a framework-based methodology would help in the identification of various elements of financial statements and the identification of the appropriate IFRS standards that needs to be applied (Hodgdon, et al., 2011; Wells 2011).

\subsection{Saudi Labour Market}

The Saudi labour market is unique in nature. The market, which is segmented, has significant numbers of expatriate employees. Saudi nationals with better educated normally are attracted and interested in joining public sector/government jobs. This is presumably due to better wages and generous fringe benefits. They also have job security, higher social status, and retirement schemes with pension. Private sector depends heavily on expatriate labour. Further expatriates are available for fixed terms and contract jobs under the sponsorship of Saudis.

Of the overall working-age population, the Saudi youth aged between 20 and 29 years constitute $31 \%$. Of the many uniqueness of Saudi labour market, recently the labour market witnessed a higher level of labour participation. However, the employment growth though was lower, remained positive. This pushed up the rate of unemployment. Yet another uniqueness of the market was that the unemployment rate of females increased faster than males. The unemployment of youth also has risen marginally. It is also worth noting that the rate of unemployment rose in spite of creation of a large number of jobs. However, it was found that majority of these newly jobs went to were secured by non-Saudis. Thus in 2016, the Saudi job market presented a total divergence from other economic indicators. For instance, while there was a sort of slowdown in the year, the net employment rose by about 892 thousand. Another silver lining was that employers showed a willingness to hire young Saudis youth.

Using the statistical data available with the General Authority for Statistics, the Jadwa Investment (2016) found a skill mismatch between the needs of the private sector employers and the Saudi job-seekers. They identify this as the major obstacle in the way of reformation of Saudi labour market. They are also of the opinion that the segmentation done between Saudis and expatriate employees with respect to working conditions like wages, work time, skills, etc. are the important factors that make private sector's to hire non-Saudis. Further, the wage rates of expatriates are lower and non-wages benefits are also lesser (Al-Asmari, 2008).

Saudi Arabia and most other countries in the Gulf Cooperation Council (GCC) having embarked on formulating distinct labour market strategies aimed at enhancing employment potential for nationals. This is planned to be accomplished within the framework of economic and structural reforms. The employment objectives are to be achieved through a number of measures touching upon the quantity, quality, and price aspect of labour force (Al-Asmari, 2008). A general increase in the labour market is definitely and most likely to have a positive impact on the need for fresh graduates who have specialised in accounting discipline.

Therefore, there is a definite need to have a peep into the prospects of employment needs, potential as well as employability of accounting graduates in the kingdom. There is also a need to find out the convenience of accounting education of the kingdom in churning out industry ready graduates ideal for the unique labour market conditions. Based on the review of literature the objectives of the study are set as under. 


\section{Objectives of the study}

The following objectives have been identified for the study:

- To identify the skills and knowledge offered by the Accounting program with the requirements of the Saudi labour market,

- To identify the most important components of the educational system in the accounting program which has an impact on the quality of accounting education,

- To identify the weaknesses and shortcomings in the program from the view point of both graduates, students, teaching staff and practitioners.

In tandem with the above objectives, the following hypotheses were formulated for the study:

Hypothesis 1: Accounting program provides adequate knowledge and skills required for the Saudi labour market.

Sub Hypotheses:

$\mathrm{H} 1_{\mathrm{a}}$ Accounting education provides adequate knowledge required by the Saudi labour market.

$\mathrm{H} 1_{\text {b: }}$ Accounting education provides students with intellectual skills required by the Saudi labour market. $\mathrm{H} 1_{\mathrm{c}}$ : There is a statistically significant difference between the accounting technical and practical skills offered by the accounting education and which required by the Saudi labour market.

$\mathrm{H} 1_{\mathrm{d}}$ : There is a statistically significant difference between the accounting interpersonal and communication skills offered by the accounting education and which required by the Saudi labour market.

\section{Methodology}

A comprehensive methodology has been adopted to conduct the present study. A structured online questionnaire was used to collect the data. The questionnaire was comprehensive in nature. Data was collected online from a total of 914 respondents for a period of four weeks. Since the questionnaire was administered online and all the items were made compulsory, there were no missing data and all the 914 responses could be used for the study. Demographic information like education, rank, gender, etc. were gathered from the respondents. Separate sets of demographic data were collected from students, faculty and professionals.

The study has adopted a "triangular approach" which involved level seven and eight accounting programs students (Final year students), accounting programs teaching staff (University Professors), and practitioners as proposed by Rosenberg et al. (2012). This method is ideal as it takes into consideration diverse views of employability, which is likely to provide a comprehensive view (Sulphey, 2015). As such the respondents included students $(258-28.2 \%)$, faculties $(198-21.7 \%)$ and practitioners $(458-50.1 \%)$ in the field of accounting. There were 572 males $(62.6 \%)$ and 342 females (37.4\%). The educational background of the sample varied drastically. The details are presented in Table 3.

Table 3

Breakup of the sample based on qualification

\begin{tabular}{clcc}
\hline No & Qualification & N & Per cent \\
\hline 1 & Up to Bachelor level & 132 & 14.4 \\
2 & Bachelor degree & 472 & 51.6 \\
3 & Higher diploma & 12 & 1.2 \\
4 & Master degree & 182 & 19.9 \\
5 & Doctorate degree & 116 & 12.7 \\
\hline
\end{tabular}


The details of the samples with professional qualifications in Accounting were also collected. There was wide diversity with respect to the professional qualifications. Many of them had international professional qualifications. The details are presented in Table 4.

Table 4

Details of professional qualifications of the sample

\begin{tabular}{clcc}
\hline No & Qualification & No & Per cent \\
\hline 1 & SOCPA & 90 & $46 \%$ \\
2 & CPA & 20 & $10 \%$ \\
3 & ACCA & 10 & $5 \%$ \\
4 & CIA & 18 & $9 \%$ \\
5 & CA & 6 & $3 \%$ \\
6 & CMA & 14 & $7 \%$ \\
7 & Cert. IFRS & 2 & $1 \%$ \\
8 & VAT Specialists & 12 & $6 \%$ \\
9 & Others & 24 & $12 \%$ \\
\hline \multicolumn{2}{c}{ Total } & 196 & $100 \%$ \\
\hline
\end{tabular}

Majority of the sample with professional qualification (90) were qualified from SOCPA (Saudi Organization of Certified Public Accountants). The sample included respondents with international qualifications from USA like CPA, ACCA, CMA, etc. A few were IFRS (2) and VAT (12) specialists. All these aspects about the respondents point towards the fairly wide diversity of the sample collected for the study.

The sample had varying years of experiences in their respective professions. It ranged from less than a year to over 20 years. The average experience was found to be 7.34 years. The details of the professional experience of the sample are presented in Table 4:

Table 4

Breakup of the sample based on experience

\begin{tabular}{clcc}
\hline No & \multicolumn{1}{c}{ Years of experience } & N & Percent \\
\hline 1 & No experience & 246 & 26.9 \\
2 & Up to 5 years & 352 & 38.5 \\
3 & From 6 to 10 years & 164 & 17.9 \\
4 & From 11 to 15 years & 76 & 8.3 \\
5 & From 16 to 20 years & 50 & 5.5 \\
5 & More than 20 years & 26 & 2.8 \\
\hline
\end{tabular}

The second part of the questionnaire consisted of four variables - accounting knowledge, intellectual skills, technical and practical skills, and interpersonal skills. There were 49 items spread in all the four variables. The breakup of items across variables is presented in Table 5:

Table 5

Breakup of items across variables

\begin{tabular}{clcc}
\hline No & \multicolumn{1}{c}{ Variable } & Number of items & Cronbach's alpha \\
\hline 1 & Accounting knowledge & 25 & 0.955 \\
2 & Intellectual skills & 6 & 0.933 \\
3 & Technical and practical skills & 6 & 0.889 \\
4 & Interpersonal skills & 12 & 0.953 \\
\hline & Total & 49 & 0.976 \\
\hline
\end{tabular}

The reliability of the questionnaire was tested using Cronbach's $\alpha$ and the values are presented in Table 5. Reliability assesses the power and precision of the scale in measuring the concept (Kerlinger, 1986; DeVellis, 1991). Reliability between the items of a scale means it possesses a good inter-item correlation. It can be observed that all values exceed the rule of the thump stipulated by Nunnally (1978). This indicates that the tool used in the examination is reliable. To further test the usability of the questionnaire, 
the inter-variable correlation was also calculated and the details are presented in Table 6. According to Churchill (1979), if the correlations were low, it would indicate that the variables do not belong to the appropriate domain. In the present case, all the correlations were found to be significant at 0.01 level, signifying its unity towards the domain of employability.

Table 6

Pearson Correlations

\begin{tabular}{|c|c|c|c|c|c|}
\hline Skills & $\begin{array}{l}\text { Accounting } \\
\text { Knowledge }\end{array}$ & $\begin{array}{c}\text { Intellectual } \\
\text { Skills }\end{array}$ & $\begin{array}{c}\text { Technical / } \\
\text { Practical skills }\end{array}$ & $\begin{array}{c}\text { Interpersonal \&Com- } \\
\text { munication Skills }\end{array}$ & $\begin{array}{c}\text { Knowledge \& } \\
\text { Skills for Market }\end{array}$ \\
\hline Accounting Knowledge & 1 & 0.756 & 0.804 & 0.624 & 0.881 \\
\hline Intellectual & & 1 & 0.769 & 0.723 & 0.913 \\
\hline Technical and Practical & & & 1 & 0.709 & 0.916 \\
\hline Interpersonal / Communication & & & & 1 & 0.862 \\
\hline Labour Market & & & & & 1 \\
\hline
\end{tabular}

\section{Findings}

For testing of various hypotheses formulated for the study, the data has been analysed using t-test and correlation. The details of the analysis are presented in the following sections.

Table 7

Results of $\mathrm{t}$ test for Accounting knowledge and skills

\begin{tabular}{clcccc}
\hline \multicolumn{1}{c}{ Variable } & Mean & SD & \multicolumn{1}{c}{ S } & Sig. (2-tailed) \\
\hline 1 & Accounting Knowledge & 3.47 & .81 & 17.50 & 0.000 \\
2 & Intellectual Skills & 3.20 & .98 & 6.14 & 0.000 \\
3 & Technical \& Practical skills & 3.35 & .90 & 11.62 & 0.000 \\
4 & Interpersonal \& Communication Skills & 3.37 & .95 & 11.80 & 0.000 \\
5 & Knowledge \& Skills for Labour Market & 3.35 & .81 & 12.87 & 0.000 \\
\hline
\end{tabular}

Note: $\mathrm{N}=914$

\subsection{Accounting knowledge}

The level of accounting knowledge of the students was assessed through 25 items. It can be observed from the above table that the actual mean for Accounting Knowledge (based on the first hypothesis) is 3.47, which is greater than the elementary mean of 3 . The value of $t$ was 17.506 greater than $t_{a}$ which is equal to 1.962. This indicates that this determinant lies within the acceptable level. By following the elements of this variable, it found that this result came from the most elements. This shows that the accounting students have the required set of generic skills that were stated in the works of Barrie (2006) and Daff et al. (2012). Thus, based on the values in Table 7, the alternative hypothesis is rejected and the null hypothesis that "Accounting education provides adequate knowledge required by the Saudi labour market" is accepted.

There are however, scope for including certain associated accounting topics in the curriculum of accounting programs. A few of them include certain special accounting issues such as accounting of hospitals, hotels, colleges, branches, non-for profit organizations, etc. There is also a scope for including in-depth details about corporate social responsibility (CSR).

\subsection{Intellectual Skills}

The second hypothesis is with respect to intellectual skills. Six items were used to assess this skill. It can be observed from Table 7 that the actual mean is 3.20, it is greater than 3 (elementary mean). The value of $t$ was 6.145, which is greater than $t_{a}$. This is an indication that this variable is in the acceptable level. Therefore, the null hypothesis is accepted, which states that "Accounting education provides students 
with intellectual skills required by the Saudi labour market". The need for intellectual skills has been highlighted by IAESB in its 2015 release. It has also been found to be an important requirement towards employability by Bui and Porter (2010), and recently by Tan and Fawzi (2017). The importance of intellectual skills has been emphasised by Tan and Fawzi (2017) to help accountants deal with issues arising out of routine aspects like cost, revenue, investment, etc. It would also facilitate the solving of problems, making the required arguments, etc. The present study has found that the Accounting education in Saudi Arabia provides the students with the intellectual skills required by the Saudi labour market. However, skills like the abilities of identification and solving of complex and unfamiliar problems need to be further improved.

\subsection{Technical and practical skills}

Six items were used to assess the technical and practical skills of the students. Statistically significant difference between the accounting technical and practical skills offered by the accounting education was found in the analysis. It can be observed that the actual mean is 3.35, which is greater than the elementary mean. Further, the value of $t$ was 11.621, which is greater than $t a$. This in an indicator that the technical and practical skills offered by the accounting education lies within acceptable level. Consequently, the null hypothesis which states that "There is a statistically significant difference between the accounting technical and practical skills offered by the accounting education and which required by the Saudi labour market" is rejected and the alternative hypothesis is accepted. The present work has thus found that the accounting education in Saudi Arabia provides accounting students with the necessary technical and practical skills required in the labour market.

The need for technical skills has been identified as early as in 1993 by Birkett, which has been emphasised by Tan and Fawzi (2017). The 2015 release IAESB has also highlighted the need for technical and practical skills. Sandifer (2018) has highlighted the same in a recent study. However, there is a definite requirement to improve certain technical and practical skills associated with risk analysis and accounting information systems.

\subsection{Interpersonal and communication skills}

The need for interpersonal and communication skills for accounting students have been stated in multitude of studies (Barac, 2009; Kavanagh \& Drennan, 2008; Lowden, et al. 2011; Tempone et al., 2012). The present study has attempted to assess the level of interpersonal and communication skills of the accounting students. The details are presented in Table 7.

12 items were used to assess the level of interpersonal skills of the accounting students. It can be observed from Table 7 that the actual mean is 3.37, which is well above the elementary mean. T value of $t$ was 11.807, which is greater than $t_{a}$, which is an indicator that this variable is lying within the acceptable levels. Therefore, the null hypothesis which states that "There is a statistically significant difference between the accounting interpersonal and communication skills offered by the accounting education and which required by the Saudi labour market" is rejected and the alternative hypothesis is accepted. It can be inferred that the accounting students of Saudi Arabia have the required interpersonal and communication skills, which is indispensable for the accounting profession. This is in tandem with the studies of Lowden et al. (2011) and Tempone et al. (2012)

\subsection{Overall employability of accounting graduates}

To test the hypothesis "General accounting programs provide adequate knowledge and skills required for the Saudi labour market", the overall score was subjected to $t$-test. The overall mean score was found to be 3.35 with a standard deviation of .81. The $t$-value was 12.86 , which is significant. The mean is greater than the elementary mean of three, and the value of $t$ was greater than $t a$. In general, through the testing 
of these hypotheses, it was possible to assess the level of adequacy of knowledge and skills offered by the accounting programs in Saudi Arabia.

As stated earlier, the present study had adopted a "triangular approach" involving three categories of respondents (Rosenberg et al., 2012), which included graduates, faculty, and practitioners. Though not triangular, a similar methodology was adopted by Hakim (2016) when he assessed the level of preparedness of Accounting Graduates through comparing the perceptions of accounting employees and their employers. The present study has however, included all the three relevant stakeholders. Therefore, analysis was done to find out the overall perception of all the three types of respondents and the results are presented in Table 8. The results show that all the categories of respondents perceive that the Accounting education in Saudi Arabia offers the required employability skills for the labour market. This pattern of perception was observed in all the four variables, and the resultant overall score. The different variables in the overall employability skills were as per the findings of Zureigat (2015) conducted earlier in Saudi Arabia.

Table 8

One-Sample $t$ test of Accounting Education offered and Requirements by the Labour Market

\begin{tabular}{|c|c|c|c|c|c|c|}
\hline Variables & Job Status & $\mathrm{N}$ & Mean & Std. & $t$ & Sig. (2-tailed) \\
\hline \multirow{4}{*}{ Accounting Knowledge } & University Professors & 198 & 3.49 & .80 & 8.650 & .000 \\
\hline & Accounting Students & 258 & 3.57 & .87 & 10.513 & .000 \\
\hline & Practitioners & 458 & 3.40 & .76 & 11.130 & .000 \\
\hline & Total & 914 & 3.47 & .81 & 17.506 & .000 \\
\hline \multirow{4}{*}{$\begin{array}{l}\text { Accounting Intellectual } \\
\text { Skills }\end{array}$} & University Professors & 198 & 3.25 & .87 & 3.983 & .000 \\
\hline & Accounting Students & 258 & 3.40 & .97 & 6.596 & .000 \\
\hline & Practitioners & 458 & 3.07 & 1.00 & 1.396 & .163 \\
\hline & Total & 914 & 3.20 & .98 & 6.145 & .000 \\
\hline \multirow{4}{*}{$\begin{array}{l}\text { Accounting Technical and } \\
\text { Practical skills }\end{array}$} & University Professors & 198 & 3.28 & .83 & 4.716 & .000 \\
\hline & Accounting Students & 258 & 3.43 & .96 & 7.180 & .000 \\
\hline & Practitioners & 458 & 3.33 & .90 & 7.874 & .000 \\
\hline & Total & 914 & 3.35 & .90 & 11.621 & .000 \\
\hline \multirow{4}{*}{$\begin{array}{l}\text { Accounting Interpersonal } \\
\text { and Communication Skills }\end{array}$} & University Professors & 198 & 3.32 & .87 & 5.158 & .000 \\
\hline & Accounting Students & 258 & 3.58 & .97 & 9.558 & .000 \\
\hline & Practitioners & 458 & 3.28 & .96 & 6.213 & .000 \\
\hline & Total & 914 & 3.37 & .95 & 11.807 & .000 \\
\hline \multirow{4}{*}{$\begin{array}{l}\text { Accounting Knowledge } \\
\text { and Skills needed in La- } \\
\text { bour Market }\end{array}$} & University Professors & 198 & 3.33 & .75 & 6.254 & .000 \\
\hline & Accounting Students & 258 & 3.49 & .85 & 9.294 & .000 \\
\hline & Practitioners & 458 & 3.27 & .80 & 7.125 & .000 \\
\hline & Total & 914 & 3.35 & .81 & 12.873 & .000 \\
\hline
\end{tabular}

In addition to the above analysis, the respondents were classified based on the scoring. Classification was made in the following manner:

\begin{tabular}{ll}
$\quad$ Group & \multicolumn{1}{c}{ Scoring } \\
High group & Mean plus half of SD $(166.37+1 / 2 \times 38.32=185.53)$ \\
Low group & Mean minus half of SD $(166.37-1 / 2 \times 38.32=147.21)$ \\
Medium group & Those having scores between the high and low groups
\end{tabular}

This grouping has provided some interesting and noteworthy results which are provided in Table 9. It can be observed that $30 \%$ of the respondents are having high opinion about the level of accounting education, and it is ideal to meet the requirements of the labour market in the Kingdom of Saudi Arabia. Another $40 \%$ belong to the middle group, together making it a net of $70 \%$ of the respondents (belonging various classifications), who are of the opinion that accounting education in the country is meeting the market requirements. While $30 \%$ of the respondents are having low opinion about accounting education meeting the labour market requirements of the country. This finding confirms the results of the earlier analysis. An attempt was also made to find out the groupings based on the various classifications like 
professors, students and practitioners. The details presented in Table 9 show that the students (74\%) hold in high esteem the capability of the accounting program to meet the labour requirements of the country. This is indeed a welcome sign, though there are many things that need to be done to make the program of high utility in the labour market.

Table 9

Grouping of the sample

\begin{tabular}{cccc}
\hline Job Status & Group Rank & N & Per cent \\
\hline & High & 62 & 31 \\
& Medium & 70 & 35 \\
University Professors & Low & 66 & 34 \\
& Overall & 198 & 100 \\
\hline \multirow{3}{*}{ Accounting Students } & High & 90 & 35 \\
& Medium & 88 & 34 \\
& Low & 80 & 31 \\
& Overall & 258 & 100 \\
\hline \multirow{3}{*}{ Practitioners } & High & 122 & 27 \\
& Medium & 206 & 45 \\
& Low & 130 & 28 \\
& Overall & 458 & 100 \\
\hline & High & 274 & 30 \\
& Medium & 364 & 40 \\
& Low & 276 & 30 \\
& Overall & 914 & 100 \\
\hline
\end{tabular}

A matter of concern is that only $27 \%$ of the practitioners are there in the high group, but $45 \%$ are in the middle group, which is heartening, thus making it a total of $73 \%$. However, this aspect needs to be provided the required importance as it the practitioners who need to appoint the graduates. There is a definite need to look from the position of the practitioners, and a study needs to be taken to find out the reason behind this difference in perception.

\section{Recommendations}

Based on the review of literature and opinions expressed by stakeholders during the course of the survey, a few recommendations related to the knowledge and skills required to improve the outcomes of the accounting programs are presented. These recommendations will also help in reducing the gap in the requirements of the Saudi labour market:

1. The curriculum needs to be developed in accordance with international accounting standards and international financial reporting standards. It is noteworthy that Saudi Arabia has adapted these standards in 2017.

2. Inclusion of the certain topics which are yet to find its presence in the study plan. Notable among them are external and internal audit, accounting of financial institutions and insurance companies.

3. Requirement of training the students on computer applications in accounting, especially the software that are currently in use in the market.

4. As field training helps the students in the acquisition of first-hand knowledge of what they are expected to do on the job, there is a need to increase the credit hours of field training. This will go to a long way in involving the industry in increasing the practical knowledge of the students.

5. Adoption of case studies method of teaching, wherein latest case incidents are discussed will also help the students in gaining required perspective of the real life situation.

6. Associating faculty members with professional associations and organizations so that they are able to acquire the required practical and professional knowledge. 
7. Initiation of industry mentoring program, wherein the industry is provided greater say in the development of curriculum and its delivery. This will facilitate to churn out industry ready graduates who are assets for the nation.

\section{Conclusion}

The study was undertaken to assess the employability of accounting graduates of Saudi Arabia. The study assessed the convenience of accounting education towards providing employability for accounting graduates based on the unique requirements of Saudi labour market. The perceptions of three stakeholders in accounting education were considered for the study - the students, the accounting faculty and the practitioners. The study has found that the accounting education in Saudi Arabia is capable of providing the required employability skills for the students. All the stakeholders from whom data has been collected have expressed this view. Nevertheless there are many things that need to be done to make the program of high utility in the labour market. Such as; scope for including certain associated with accounting topics in the curriculum of accounting programs and certain special accounting issues. There is a definite requirement to improve certain technical and practical skills associated with risk analysis and accounting information systems. Furthermore, there is also a scope of providing skills like the abilities of identification and solving of complex and unfamiliar problems which need to be further improved.

\section{Acknowledgement}

The author acknowledges that, the Deanship of Scientific Research at Prince Sattam Bin Abdulaziz University supported this project under the research project number 2017/02/7451.

\section{References}

Abayadeera, N., \& Watty, K. (2014). The expectation-performance gap in generic skills in accounting graduates: Evidence from Sri Lanka. Asian Review of Accounting, 22(1), 56-72.

Al-Asmari, M. (2008). Saudi labor force: Challenges and ambitions. JKAU: Arts \& Humanities, 16(2), 19-59.

AlMotairy, O. S., \& Stainbank, L. J. (2014). Compliance with international education standards in Saudi Arabia: policy and educational implications. Journal of Business Studies Quarterly, 5(4), 5.

Athiyaman, A. (2001). Graduates' Perception about Business Education: an exploratory research. Journal of Further and Higher Education, 25(1), 5-19.

Awayiga, J. Y., Onumah, J. M., \& Tsamenyi, M. (2010). Knowledge and skills development of accounting graduates: The perceptions of graduates and employers in Ghana. Accounting Education: an international journal, 19(1-2), 139-158.

Barac, K. (2009). South African training officers' perceptions of the knowledge and skills requirements of entry-level trainee accountants. Meditari Accountancy Research, 17(2), 19-46.

Barrie, S. C. (2006). Understanding what we mean by the generic attributes of graduates. Higher education, 51(2), 215-241.

Barth, M. E. (2008). Global financial reporting: Implications for US academics. The Accounting Review, 83(5), 1159-1179.

Birkett, W. P. (1993). Competency based standards for professional accountants in Australia and New Zealand: Discussion Paper. Link Printing.

Bui, B., \& Porter, B. (2010). The expectation-performance gap in accounting education: An exploratory study. Accounting Education: an international journal, 19(1-2), 23-50.

Carmona, S., \& Trombetta, M. (2008). On the global acceptance of IAS/IFRS accounting standards: The logic and implications of the principles-based system. Journal of Accounting and Public Policy, 27(6), 455-461.

Churchill Jr, G. A. (1979). A paradigm for developing better measures of marketing constructs. Journal of marketing research, 16(1), 64-73. 
Cranmer, S. (2006). Enhancing graduate employability: best intentions and mixed outcomes. Studies in Higher Education, 31(2), 169-184.

Crawford, L., Helliar, C., \& Monk, E. A. (2011). Generic skills in audit education. Accounting Education: an international journal, 20(2), 115-131.

Daff, L., De Lange, P., \& Jackling, B. (2012). A comparison of generic skills and emotional intelligence in accounting education. Issues in Accounting Education, 27(3), 627-645.

Dandago, K. I., \& Shaari, N. A. B. (2013). Effects of focus of accounting research on the quality of accounting education in Malaysian Universities. Asian Economic and Financial Review, 3(10), 1371.

De Lange, P., Jackling, B., \& Gut, A. M. (2006). Accounting graduates' perceptions of skills emphasis in undergraduate courses: an investigation from two Victorian universities. Accounting and Finance, 46(3), 365-386.

DeVellis, R. F. (1991). Applied social research methods series, Vol. 26. Scale development: Theory and applications. Thousand Oaks, CA, US: Sage Publications, Inc.

Gati, I. (1998). Using career-related aspects to elicit preferences and characterize occupations for a better person-environment fit', Journal of Vocational behaviour, 52(3), 343-356.

Hakim, R. R. C. (2016). Are accounting graduates prepared for their careers? A comparison of employees' and employers' perceptions. Global Review of Accounting and Finance, 7(2), 1-17.

Hassall, J. T. J., Montano J. L. A. \& Anes, J. A. D. (2005). The vocational skills gap for management accountants: the stakeholders' perspectives. Innovations in Education and Teaching International, 40(1), 78-88.

Hodgdon, C, Hughes, S. B. \& Street, D. L. (2011). Framework-based teaching of IFRS judgements. Accounting Education, 20(4), 415-439.

International Accounting Education Standards Board (IAESB) (2015). International Education Standard (IES) 3 Initial Professional Development - Professional Skills.

Jackling, B., \& Sullivan, C. (2007). Financial planners in Australia: an evaluation of gaps in technical and behavioral skills. Financial Services Review, 16(3), 211.

Jackling, B., \& De Lange, P. (2009). Do accounting graduates' skills meet the expectations of employers? A matter of convergence or divergence. Accounting Education: An International Journal, 18(4-5), 369-385.

Jackling, B., de Lange, P. A., \& Natoli, R. (2012). Transitioning to IFRS in Australian classrooms: impact on teaching approaches. Issues in Accounting Education, 28(2), 263-275.

Jackson, D., \& Chapman, E. (2012). Non-technical skill gaps in Australian business graduates. Education + Training, 54(2/3), 95-113.

Jones, G., \& Abraham, A. (2009). The value of incorporating emotional intelligence skills in the education of accounting students. Australasian Accounting, Business and Finance Journal, 3(2), 4.

Kavanagh, M. H., \& Drennan, L. (2008). What skills and attributes does an accounting graduate need? Evidence from student perceptions and employer expectations. Accounting \& Finance, 48(2), 279300.

Kim, T. S., Ghosh, B. C., \& Meng, L. A. (1993). Selection criteria: Perception gap between employers and accounting graduates. Singapore Accountant, 9(4), 32-33.

Klibi, M. F., \& Oussii, A. A. (2013). Skills and attributes needed for success in accounting career: Do employers' expectations fit with students' perceptions? Evidence from Tunisia. International Journal of Business and management, 8(8), 118.

Lin, Z. J., Xiong, X., \& Liu, M. (2005). Knowledge base and skill development in accounting education: Evidence from China. Journal of Accounting Education, 23(3), 149-169.

Lowden, K., Hall, S., Elliot D., \& Lewin, J. (2011). Employers' perceptions of the employability skills of new graduates, London: Edge Foundation.

Mallak, A. L. (2012). Accounting students' need for important generic and technical accounting skills in university education and as accountants in the workplace (Doctoral dissertation, University of Waikato). 
Muda, S., Che-Hassan, A., \& Abdul-Samad, R. (2009). Requirement of soft skills among graduating accounting students: Employers and UITM students' View, Shah Alam. Research Management Institute, 1-58.

Nunnally, J. C. (1978). Psychometric theory (2nd Ed.). New York: McGraw-Hill Book Company.

Parham, A. G., Noland, T. G., \& Kelly, J. A. (2012). Accounting Majors' Perceptions of Future Career Skills: An Exploratory Analysis. American Journal of Business Education, 5(1), 29-36.

Rosenberg, S., Heimler, R., \& Morote, E. S. (2012). Basic employability skills: a triangular design approach. Education + Training, 54(1), 7-20.

Sandifer, L. (2018). Knowledge, Technical Skills, and Employability Skills Required of Accounting Graduates: Perceptions of Certified Public Accountants in Mississippi. Unpublished Dissertation submitted to The University of Southern Mississippi, Dissertations. 1510.

Senan, N. A. M. (2018). Developmental review program impact on enhancing the effectiveness of" Teaching and Learning" in accounting program: a case study in a Saudi University. Entrepreneurship and Sustainability Issues, 6(2), 1001-1017.

Siegel, G., Sorensen, J. E., Klammer, T., \& Richtermeyer, S. B. (2010). The ongoing preparation gap in accounting education: A call to action. Management Accounting Quarterly, 11(3), 41.

Sugahara, S., \& Coman, R. (2010). Perceived Importance of CPA's Generic Skills: A Japanese Study. Asian Journal of Finance \& Accounting, 2(1), 1-24.

Sulphey, M. M., \& Alkahtani, N. S. (2018). Academic excellences of business graduates through nudging: prospects in Saudi Arabia. International Journal of Innovation and Learning, 24(1), 98-114.

Sulphey, M. M., Al-Kahtani, N. S., \& Syed, A. M. (2018). Relationship between admission grades and academic achievement. Entrepreneurship and Sustainability Issues, 5(3), 648-658.

Sulphey, M. M. (2015). Patterns of employability skills among business students. IPE Journal of Management, 5(2), 57.

Sulphey, M. M. (2017). Game-based learning as an aid for extenuating higher education sector issuesThe case of Saudi Arabia. International Journal of Simulation, Systems, Science and Technology, 18(1), 6-1.

Tan, L. M., \& Fawzi, L. (2017). Employability Skills required for Accountants. SHS Web of Conference, 34, 1-9. https://doi.org/10.1051/shsconf/20173406001

Tempone, I., Kavanagh, M., Segal, N., Hancock, P., Howieson, B., \& Kent, J. (2012). Desirable generic attributes for accounting graduates into the twenty-first century: The views of employers. Accounting Research Journal, 25(1), 41-55.

Usoff, C., \& Feldmann, D. (1998). Accounting students' perceptions of important skills for career success. Journal of Education for Business, 73(4), 215-220.

Wally-Dima, L. (2011). Bridging the gap between accounting education and accounting practice: The case of the University of Botswana. IUP Journal of Accounting Research \& Audit Practices, 10(4), 7-27.

Wells, M. J. (2011). Framework-based approach to teaching principle-based accounting standards. Accounting Education, 20(4), 303-316.

Yu, S. C., \& Churyk, N. T. (2013). Are students ready for their future accounting careers? Insights from observed perception gaps among employers, interns, and alumni. Global Perspectives on Accounting Education, 10, 1-15.

Zureigat, Q. M. (2015). Accounting Graduates Skills and Employers' Needs: The Saudi Case. Jordan Journal of Business Administration, 11(1), 227-238.

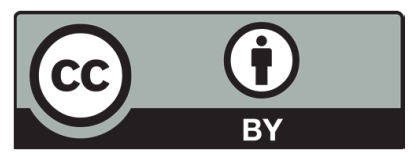

(C) 2019 by the authors; licensee Growing Science, Canada. This is an open access article distributed under the terms and conditions of the Creative Commons Attribution (CCBY) license (http://creativecommons.org/licenses/by/4.0/). 